\title{
Relationship Between Corporate Ethos and Learning and Developing Organization in Changing Economic Environment
}

\begin{abstract}
The article analyses the relationship between corporate ethos and learning organization development posed by the challenges in changing economic environment. By a various authors, different science concepts, the new conceptual model is formulated as one object of scientific research for investigation of the relationship between corporate ethos and learning and developing organization in the changing environment. There is prepared new summarized logical model for the scientific problem research of the relationship between future corporate ethos and learning and developing organization in the changing economic environment.
\end{abstract}

Keywords: corporate ethos, learning, developing organization, relationship, changing economic environment.

Straipsnyje analizuojamas ryšys tarp korporacijos etoso ir besimokančios organizacijos kintančioje ekonomikos aplinkoje. Skirtingų autorių, skirtingų mokslų teiginių pagrindu suformuluotas ryšys tarp korporacijos etoso ir besimokančios organizacijos plètotès, kaip mokslinio tyrimo objektas. Atlikus mokslinès literatūros analizę ir sisteminimą, nagrinëjamas besimokančios organizacijos procesas, jam ịtakos turintys veiksniai bei jų raiška šiandieninejje praktikoje. Parengtas naujas, apibendrintas ryšio tarp ateities korporacijos etoso ir besimokančios bei besiplètojančios organizacijos kintančioje ekonomikos aplinkoje atitikties tyrimo problemos loginis modelis.

Raktiniai žodžiai: korporacijos etosas, besimokanti, besiplètojanti organizacija, ryšys, ekonomikos pokyčiai.

\section{Introduction}

Business organizations executives regularly wrestle with the new factors / challenges of the external-macro level and business dimension level (Cole, 1994), globalization of economic processes, changes in human resources, development of modern technologies in management and marketing, changes in organization culture (Tosi et al., 1994), and ethics as the environment, shifting values and cultural contradictions, ethical and unethical, legal and illegal decisions (Henderson, 1990).

Under the influence of changing enormous macro economical problems - inflation and unemployment, economic growth and productivity, according to the authors of macro economics and micro economics P. Wonnacott, R. Wonnacott (1993; 1994), do exist the changing market structure and efficiency. And by opinion of R. Lewis 
(2002), the differences of international business world manifest with challenges of market according to corporate ethos, culture of the corporate. And, according to Ch. D. Stone (1990) and B. Garrat (1987), the developing organization has to turn one's attention to the relationship between the future corporate ethos and developing organization in changing economic environment.

Everyone today is keenly aware of and concerned about the change, about the impact of change. In order to remain competitive and even the survive, according to F. Luthans (1985), organizations must meet the tremendous challenges presented by all the areas of change. The researchers of basic economics A. J. Isachsen and C. Hamilton (1992) state that challenges posed by the changing economic market create the new profit-making prospects, the demands concerning the capacity for reorganization in corporate, the changes in mentality and attitudes, even the challenges to the authorities.

W. M. Hoffman, J. N. Moore (1990) viewed the future corporate ethos as "developing the moral corporation". A corporation with the best will in the competitive market are obliged to be responsible for morality ethics, that is the possess the corporate ethos, and, according to the opinion of M. G. Velasquez (1992), have to create the image-building tactic (creating the appearance of being thoughtful, honest, sensitive, on the inside of important activities, well-liked, confident).

The relationship between future corporate ethos and corporate decisions, globalization and competition, profit and aspiration to benefit and macro-environment challenges are ordinary problems of organizations / business world behavior in a changing economic environment in the globalized economy. However, in this case these problems are not investigated and there is no methodological research here. The problem of the research is lack understanding of the meaning of the relationship between corporate ethos and learning organization and developing organization in changing economic environment. The research problem of the paper has been of the methodical measures: first, to formulate and determine the conceptual model for learning and developing organization research process in the changing economic environment; second to study and investigate the theoretical and practical aspects of the relationship between future corporate ethos and learning and developing organization in the changing economic environment; third, to develop suggestions for the problem research ant to present the summarized logical background model of relationship between future corporate ethos and learning and developing organization in changing economic environment.

The object of the research is the relationship between the corporate ethos and the learning and developing organization in changing economic environment.

The aim of this research paper is to determine and to present the relationship between the future corporate ethos in the context of learning and developing organization according to the challenges posed by influences of the external macro-level factors in the changing economic environment.

\section{The objectives of the research are:}

1. To determine and to present the conceptual model for learning and developing organization research process in the changing economic environment.

2. To analyze theoretical and practical aspects of the relationship between 
future corporate ethos and learning and developing organization in the changing economic environment.

3. To present the summarized logical background model of relationship between future corporate ethos and learning and developing organization in changing economic environment.

Research methods: Analysis and synthesis of fundamental scientific literature and articles of learning and developing organization processes and its relationship between corporate ethos. The method of logical analysis and systematization of scientific determinants was employed.

In the author's research the methods analysis and systematization of fundamental scientific literature were employed and a modification of them according to the relationships between corporate ethos and learning and developing organization helps to create and to prepare new conceptual model of this research.

\section{Conceptual model for research process of learning and developing organization in changing economic environment}

The identification of the relationship between corporate ethos and learning and developing organization in changing economic environment is a complex body of knowledge of various scientific spheres of management, economics, marketing, service marketing, ethics. And so on, as well as research methodology, problems and questions about the relationship between corporate ethos and learning and developing organization.

The author of this article, according to these fundamental scientific propositions and interpretations prepared the conceptual model for research process of the relationship between corporate ethos and learning and developing organization in the changing economic environment and presented in Figure 1.

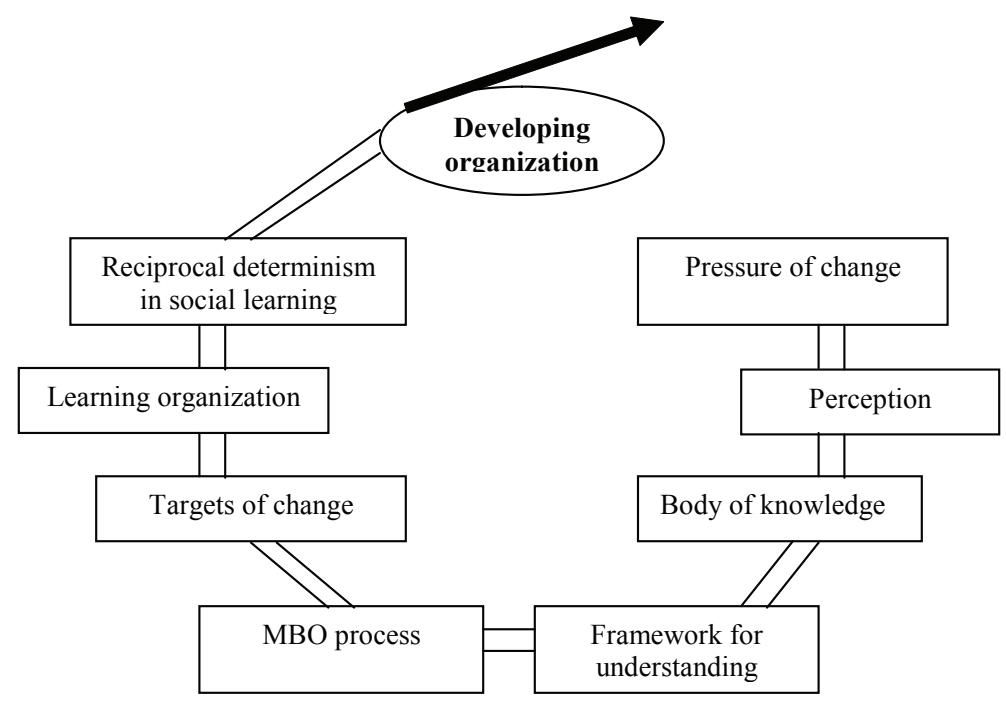

Fig. 1. The conceptual model for research process of learning and developing organization in changing economic environment 
The identification and determination of the conceptual assumptions of learning and developing organization consist of several work / analysis phases and include these conceptions:

1) Pressure for change in organization from external pressures to internal pressures

2) Perception of change

3) Body of knowledge for learning and developing organization according to the pressure and changing economic environment

4) A framework for understanding organizational behavior

5) Management by objectives for learning and developing organization

6) Targets of change according to basic change model for learning and developing organization

7) Classical conditioning model of learning

8) Reciprocal determinism in social learning includes the personal cognitions, subordinates and macro variables

\section{Analysis of theoretical and practical aspects of the relationship between future corporate ethos and learning and developing organization in the changing economic environment}

1. Pressure for change in organizations. According to H. L. Tosi, J. R. Rizzo and S. J. Carroll (1994), and F. Luthans (1995), the pressure for change in organizations is a necessary condition for a learning and developing organization. Such facts and arguments of basic economic scientists (Wonnacott, Wonnacott, 1993; 1994; Isachsen and Hamilton, 1992; Heilbroner,
1995) state, that the market economics is a constantly changing process.

Because, according to R. Heilbroner's (1995) opinion, the economic problems are for threats of crises, inflation and instability, invite problems in international production and finance, debts on a world scale. Pressure for change in organizations may be internal or external (Cole, 1994; Bowie, Buttle, 2004).

Pressure for change comes from the various external environments and its factors influence. More so in recent years, according to the author of this research disposition, since many changes have occurred in the external environment political, economic, social and cultural, technological, environmental, the factors law and order, which influence the relationship between a domestic corporate ethos and external entities (Dilworth, 1986). In addition, according to the factors of macro-level influences on corporate ethos and the corporate decisions manifested in legal and illegal, ethical and unethical resolutions (Henderson, 1990).

2. Perception of change. The authors of organizational behavior and learning and developing organization research (Tosi, Rizzo and Carol, 1994; Luthans, 1985; Castka, Bamber, Sharp and Belohaubek, 2001) define, that the perception is the process of creating and internal representation of the external world, which includes the perceptual situation and internal reaction to overt behavior. Perception is a dynamic process, a search for the best interpretation of available situation in which successful implementation of high performance teams for organization development.

3. Body of knowledge for learning and developing organization. Challenges posed by the market economy today are to ensure persistent and consistent 
growth of knowledge on economy serving the basis for learning and developing organizations.

Researchers of the knowledge-based society (Grundey, Zacharia, 2009), knowledge-based economic perspectives (Samulevičius, 2009), customers education (Skvorcova, Arandas, 2009) refer that the knowledge-based economy, consumers education, knowledge-based economy are a new stage social and economic development.

Scientists and researchers of organizational behavior, managing organizational behavior (Luthans, 1985; Tosi, Rizzo and Carroll, 1994) and consumer behavior (Engel, Blackwell and Miniard, 1995) define knowledge as especially important for the future of organizational behavior change to the usage of knowledge in customer behavior and very recent.

Nowadays some researchers (Grundey, Zacharia, 2009) perceive, that the most competitive and dynamic knowledgebased economic in the world is becoming an inseparable part of human development, of information society and knowledge of economy development.

Some researchers - P. Wonnacott and R. Wonnacott $(1993,1994)$, A. J. Isachsen and C. B. Hamilton (1992) - accented, that the market economy is in a state of continual change. In present day a new approach towards knowledge-based perspectives is necessary.

F. Luthans (1985) according to the background of the behavioral sciences and the relationship between academic disciplines - arts and sciences (humanities, physical and biological sciences), social sciences (economics, history, political sciences) and of the behavioral sciences (anthropology, cultural anthropology, sociology, psychology and social psychology) present a picture, which summarizes the relationship between the practical behavioral problems facing today's human resources managers and customers answered questions, research methodology and the existing body of knowledge. (For more information on the questions and answers, which have to be answered by a well managed business strategy of the business enterprises development see the author's published paper (2009)).

4. Framework for understanding organizational behavior. The framework for understanding organizational behavior according to H. L. Tosi, J. R. Rizzo and S. J. Carroll (1994) includes building blocks of organizational behavior (organizations, individuals and groups), managerial processes and effectiveness (key result areas).

In this framework there can be seen the building blocks that focus on understanding individuals, groups and organizations according to the body knowledge between corporate ethos and learning and developing organization in the changing economic environment. However, the life of economics and processes of industry, according to W. Streeckas (2002), are so diverse and change so quickly, that the state can never keep pace with necessary legislation according expectations of the people.

Now in present day the researchers (Skvorcova, Arandas, 2009; Samulevičius, 2009) produce evidence that the consumer education helps to develop consumer professional competence, that the knowledge-based economic perspectives are a new stage of social and economic development and to understand today's macroeconomic problems.

5. Management by objectives for learning and developing organization. A logical extension of goal setting is very popular, not only to setting individual objectives, 
but also to learning and developing organization and setting overall objectives of organization performance according to the challenges of changing economic environment. There is a general agreement, that the management by objectives involves a series of systematic steps that follow a process similar to the one: 1 ) Setting overall objectives and action plans; 2) Develop the organization for $\mathrm{MBO}$; 3) Setting individual objectives and action plans; 4) Periodic appraisals send feedback on progress and adjustments made; 5) Final appraisal on results.

According to H. Dürras (2002), corporation in the business world plays roles of the social organization and is perceived as a social organization. The authors of fundamentals of management (Mescon, Albert, Khedouri, 1988; Stoner, Freeman, Gilbert, 1999), according to the context of social responsibility and ethics, turn one's the attention to the changing social responsibility conception. G. Cole (1994) refers to necessity for the organizational change, according to factors of the external environment changes and influences.

6. Targets for change according to the basic change model for learning and developing organization. Pressure for change may be directed at individual, a group, or an organization. The key stages in change process, pressure for change and targets of change, according to H. L. Tossi, J. R. Rizzo and S. J. Carroll (1994), include the motivation to change, use appropriate change method and reinforcement of change.

It is necessary to turn attention to situation that the change can be planned and systematic, according to changes economic environment and challenges posed by market economy. The basic change model shows, that the pressures to change are key stages in change process in the individual, groups and whole organization dimension's levels. Pressures for change may be directed at individual, a group, or an organization. The key stages in change process, pressures to change and targets of change are shown in Figure 2.

TARGET OF CHANGE

\begin{tabular}{|c|c|c|c|}
\hline $\begin{array}{c}\text { PRESSURES TO } \\
\text { CHANGE }\end{array}$ & Individual & Group & Organization \\
\hline $\begin{array}{c}\text { Create motivation to } \\
\text { change }\end{array}$ & $\begin{array}{l}\text { - Training need analysis } \\
\text { - Performance feedback }\end{array}$ & $\begin{array}{l}\text { - Modeling } \\
\text { - Survey research }\end{array}$ & $\begin{array}{l}\text { - Action research } \\
\text { - Pilot study analysis }\end{array}$ \\
\hline $\begin{array}{l}\text { Use appropriate } \\
\text { change method }\end{array}$ & $\begin{array}{l}\text { - Training of individuals } \\
\text { - Individual counseling }\end{array}$ & $\begin{array}{l}\text { - Group training } \\
\text { - Team building }\end{array}$ & $\begin{array}{l}\text { - Change task forces } \\
\text { - System audits }\end{array}$ \\
\hline $\begin{array}{l}\text { Reinforcement of } \\
\text { change }\end{array}$ & $\begin{array}{l}\text { - Positive reactions } \\
\text { - Supervisory praise } \\
\text { - Performance success }\end{array}$ & $\begin{array}{l}\text { - Group praise } \\
\text { - Improved functioning } \\
\text { - Performance success }\end{array}$ & $\begin{array}{l}\text { - Improved functioning } \\
\text { - Praise by other } \\
\text { organizations } \\
\text { - Performance success }\end{array}$ \\
\hline
\end{tabular}

Fig 2. A Basic Change Model

Source: H. L. Tossi, J. R. Rizzo and S. J. Carroll (1994). 
7. The classical conditioning model of learning. The learning process, including socialization, is the process by which a person learns and acquires values, attitudes, beliefs, and accepted behaviors of a culture, society, organization, or group.

Learning and socialization are basic understanding, which shows how people and society in which business organizations operate acquire knowledge-based society and knowledge-based economic attitudes and skills in the changing economic environment. In the conditions of global changing market economy corporate has to understand the challenges of changing economic environment and in the same time to satisfy the consumer's wants and expectations. In the era of progress of science and technologies consumers are becoming a knowledge society. F. Luthans (1985) suggests that organization development is the modern approach to the management of change and the development of human resources that is a planned process of change in an organization's culture through the utilization of behavioral science technology research and theory. At the same time, that organization development is beginning to mature and, on one hand, it is clear that organization development is not going to be a panacea for management's problem. But on the other hand, it is also clear, that organization's development can definitely to help to meet the challenges and to become a modern and effective organization.

8. Reciprocal determinism in social learning. The reciprocal determinism in social learning includes person or leader cognitions, person or leader behavior and environment, including subordinates and environment (macro) variables. It is the social learning theory and organizational behavior theory and practice. F. Luthans
(1985) state, that the social learning theory can provide a model for continuous reciprocal interaction between the leader (including his or her cognitions) and the environment (including subordinates / followers and macro variables), and the behavior itself.

Since, that social learning and practice provides a model which includes subordinates and macro variables of the environment in which corporate operates, then the reciprocal determinism in social learning takes place in societal marketing concept (Kotler et al., 2003; Kotler, Bowen et al., 2003), including customers, society and corporate, where marketing concept and integrated marketing communication oriented to public relations, direct and interactive marketing, and consumer-oriented marketing relationship marketing systems. A relationship definition of marketing refers that marketing is to establish, maintain and change relationship with customers and other partners of the parties involved. This is achieved by mutual exchange and fulfillment of promises. According to Ch. Grönroos (1999) and E. Gummesson (1999), profits come from customer relationship and the "knowledge explosion" (Norman, 1991), and the importance of the developing and educating the people, who will be supplying services is so great, that many service companies organize their own schools and "learning experiences in retailing" (Rosebloom, 1981). The scientists of fundamentals of marketing, principles of marketing (Kotler, 2000; Kotler, Armstrong, Saunders, Wong, 2003), retail marketing (Rosenbloom, 1984), marketing for hospitality (Bowie, Buttle, 2004), marketing for hospitality and tourism (Kotler, Bowen and Makens, 2003), relationship marketing, timeshare markets and consumer behavior (Upruch, Lashley, 2006) refer to the concept of the "relationship marketing and customer loyalty". Because 
public relations models and persuasion ethics (Fawkes, 2007) can help to well-deserve reward comprehension and support of the society. Also, service marketing philosophy, according to Ch. Grönroos (1999), R. Normann (1991), is based without the knowledge services and service equality, marketing communication and corporate image, ethics managing service culture, link customers and social relationships. In the present day, the relationship between corporate ethos and learning and developing organization in changing economic environment has to be oriented towards understanding and perception to the whole complex challenges, dilemmas and problems in a market economy, posed by globalization. Because H. Düras (2002) highlights the circles, which consist three dimensions: politics, economics and culture. In the conditions of global changing market economy corporate has to understand the challenges of changing economic environment, and, in the same time, to satisfy the consumers' wants and expectations. In the era of progress of science and technologies consumers are becoming a knowledge society. F. Luthans (1985) suggests, that organization development is the modern approach to the management of change and the development of human resources, and, that is a planned process of change in an organization's culture through the utilization of behavioral science technology research and theory.

\section{The summarized logical background model for research relationship between future corporate ethos and learning and developing organization in changing external entities}

According to the different multidisciplinary sciences of economics, management, marketing, service marketing, ethics, organizational behavior, organizational culture, the author of this article prepared the new a summarized logical background model in this research sphere. It shows research relationship between future corporate ethos and learning and developing organization in the changing economic environment entities. This summarized logical background model prepared by the author of this research (2011), according to the analysis theoretical and practical aspects of the relationship between future corporate ethos and learning and developing organization in changing economic environment, is presented in Figure 3.

The relationship between future corporate ethos and learning and developing organization, and pressure for change and perception in changing environment:

1. Pressure of external environment which includes:

a) macrolevel (PESTEL) factors (political, economical, social / cultural, technological, environmental, law and order);

b) Business dimension level (BPESTEL) factors (business sector, political, economical, social / cultural, technological, environmental, law and order).

2. Pressure of internal environment factors:

a) organization structure, organizational behavior, culture, values, business ethics and etc;

b) personal learning (individual and groups);

c) goods or services, quality and price;

d) technologies, communication and etc.

This new summarized logical background model, prepared according to multidisciplinary sciences research methods and methodology. Especially, this is a 


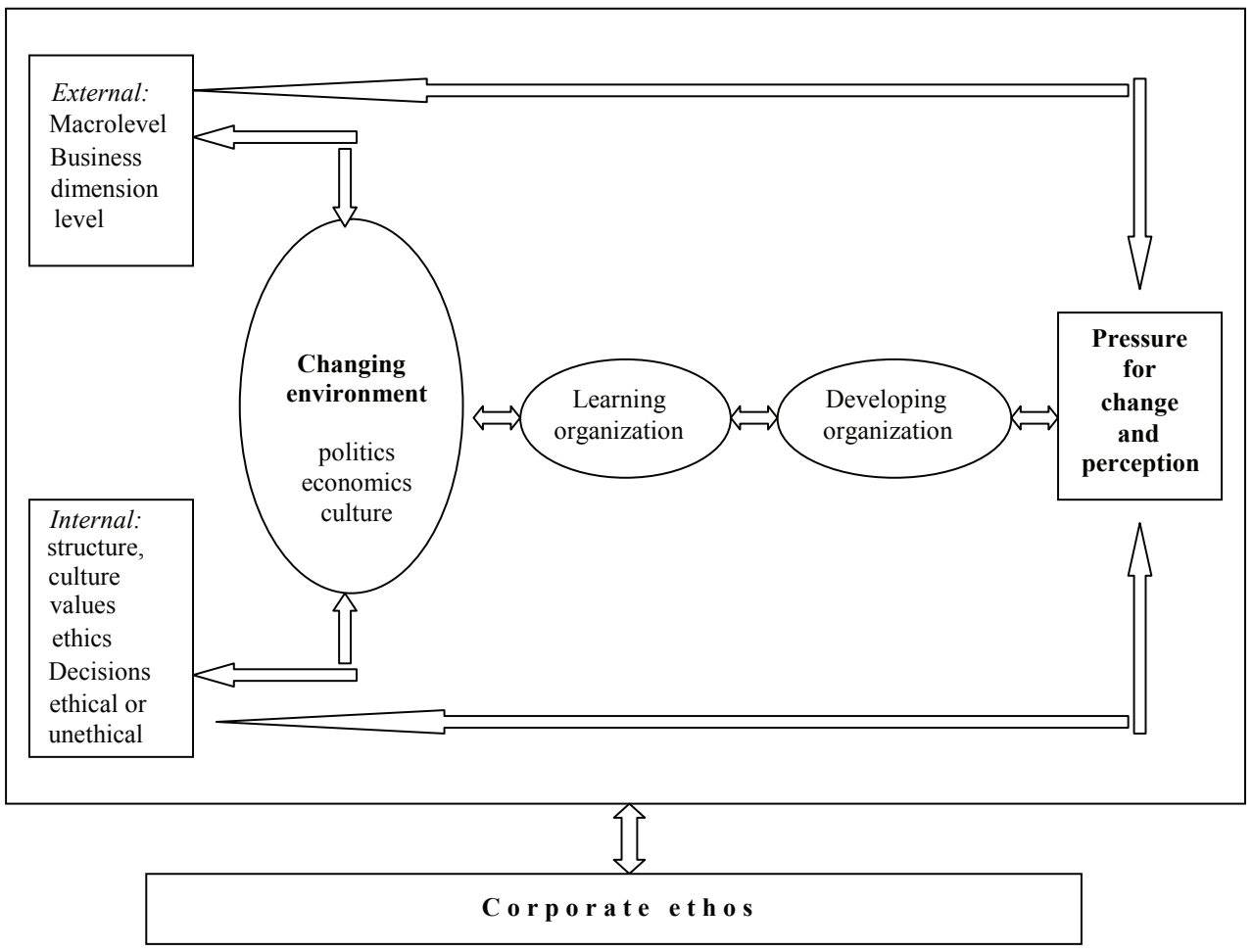

Fig.3. The summarized logical background model for research of relationship between future corporate ethos and learning and developing organization in the changing economic environment entities

Source: prepared by author.

methodology, which can help for research process of the relationship between future corporate ethos and learning and developing organization development in the changing environment of today.

\section{Conclusions}

After having analyzed the concepts of different authors and different sciences regarding the relationship between the corporate ethos and learning and developing organization in the changing economic environment, and after that having prepared a new conceptual model for the research of this problem, conclusions are made:

Today's learning organization is not a corporation only including its benevolently learning members / workers. A pressure for a change in the corporate is done by the external macro-economic macrolevel (PESTEL), business dimension level (BPESTEL) factors and challenges of market economic. Corporations, wanting to compete and to survive in the world of market, have to be in a constant change in order to react to the challenges of the market, as well as to maintain the corporate ethos and a good public image. For that matter, social marketing concept 
and integrated marketing communication strategy for environment research in which corporate operates are used.

The relationship between corporate ethos and learning organization's development is very diverse and complicated. The research of this relationship is complex, including the analysis of the pressures for change in organizations, perceptions of creating an internal representation of the external world, body of knowledge - according to relationship between problems, methodology and knowledge, and a framework for understanding organizational behavior and management by objectives process of learning and developing organization, also targets of change and reciprocal determinism in social learning process.

The prepared and presented the summarized logical background model, according to different sciences for research of relationship between future corporate ethos and learning, and developing organization in the changing economic environment, helps for the research methodology problems, connected with corporate ethos and external changing environment, that is possible external relationship of a domestic corporate ethos and external entities.

\section{References}

1. Bausch, T., Kleinfield, A., Steinmann, H. (2002). Imonių etika verslo praktikoje. Versta iš vok.k. apžvalginis straipsnis N. Vasiljevienè. Vilnius, VU KHF, Verslo etikos centras.

2. Bowie, D., Buttle, F. (2004). Hospitality marketing. Elsevier Butterworth Heinemann.

3. Castka, P., Bamber, C., Sharp, J., Belohonbek, P. (2001). Factors affecting successful implementation of high Performance teams // Team Performance Management: An International Journal. Vol. 7. No. 7/8 (43).

4. Cole, G. A. (1994). Strategic management: Theory and practice. London: Aladine Palce.

5. Dilworth, J. B. (1986). Production and operations management. Manufacturing and non-manufacturing $3^{\text {rd }}$ ed. - New York: Random House.

6. Düras, H. (2002). İmonè kaip visuomeninè organizacija / Imonių etika verslo praktikoje. Versta iš vok. k. / Red. Bausch, T., Kleinfeld, A., Steinmann, H. Apžvalginis straipsnis Vasiljevienè, N. Vilnius, VU KHF, Verslo etikos centras.

7. Engel, J. F., Blackwell, R. D., Miniard, P. W. (1995). Consumer behavior. $8^{\text {th }}$ ed. - Dryden Press.

8. Fawkes, J. (2007). Public Relations Models and Persuasion Ethics: a New Approach // Journal of Communication Management. Vol. 11, No. 4.

9. Garrat, B. (1987). The learning organization: and the need for directors who think. - London: Fantana.
10. Grönroos, Ch. (1999). Service management and marketing: management the moments of truth in service competition. - Massachusetts / Toronto: Lexington books.

11. Grundey, D., Zacharia, R. M. (2009). Knowledge-based society and ICT market policies: cross - country analysis of Lithuania and Romania // BRIDGES: Supplementary issue: Scientic Volume / Social Science in Global World: Possibilities, Challenges and Perspectives, Vol. 28, No.3.

12. Gummeson, E. (1999). Total Realtionships Marketing. - Oxford: Brutterworth - Heinemann.

13. Heilbroner, R. (1995). Didieji ekonomistai. Versta i : Robert L. Heilborner. The wordly Philosphers: The Lives, Times and Ideas of the Great Economic Thinkers. 6th ed. - Simon \& Schuster.

14. Henderson, V. E. (1990). The ethical side of enterprises // Business ethics: reading and cases in corporate morality, $2^{\text {nd }}$ ed. - New York: Mc Gran-Hill Publishing Company.

15. Hoffman, W. M., Moore, J. M (1990). Business ethics: reading and cases in corporate morality, $2^{\text {nd }}$ ed. - New York: Mc Gran-Hill Publishing Company.

16. Isachsen, A. J., Hamilton, C. (1992). Ekonomikos pagrindai / Basic Economics. - Vilnius: Alma littera. 
17. James, A. F., Stoner, R., Freeman, E., Gilbert, D. R. (1999). Vadyba / Vert. iš anglų k. Albina Trečiokaitè. Kaunas: Poligrafija ir informatika.

18. Kotler, P., Armstrong, G., Saunders, J., Wong, V. (2003). Rinkodaros principai / - Kaunas: UAB Poligrafija ir informatika.

19. Kotler, P., Bowen, J., Makens, J. (2003). Marketing for Hospitality, and Tourism. 3rd ed. - Prentice Hall.

20. Lewis, R. (2002). Kultūrų sandara. Kaip sèkmingai bendrauti su kitų tautų ir kultūrų atstovais. Vert. Iš: When Cultures Collide by Richard D. Lewis. Leidimas lietuvių k. „Alma litera“.

21. Luthans, F. (1985). Organizational behavior. 4th ed. - Mc Graw-Hill, Inc.

22. Mescon, M., Albert, M., Khedouri, F. (1988). Management. New-York: Harper\&Ron, Publisher, Inc.

23. Normann, R. (1991). Service management: strategy and leadership in service business. 2nd ed. - John Wiley \& Sons Ltd.

24. Rosenbloom, B. (1981). Retail Marketing. Random House, Inc.

25. Samulevičius, J. (2009). Knowledge - based economic perspectives in the European Union // BRIDGES: Supplementary issue: Scientific Volume / Social Sciences in Global World: Possibilities, Challenges and Perspectives. Vol. 28, No. 39.

26. Skvorcova, E., Arandas, Y. (2009) Consumers education as a method for regulation of consumers behavior in the decision - making, based on the example of Latvia // BRIDGES: Supplementary issue: Scientific Volume / Social Sciences in Global World: Possibilities, Challenges and Perspectives. Vol. 28, No. 39.

27. Stone, Ch. D. (1990). The culture of the corporation // Business ethics: reading and cases in corporate morality / N. Michael Hoffman, Jenifer Mills Moore, $2^{\text {nd }}$ ed. - New York: Mc GranHill Publishing Company.

28. Streeckas, W. (2002). Dalyvavimas priimant sprendimus kaip saviorganizacija - "Dalyvavimo priimant sprendimus”, Bertelsmann ir Hans Böckler fondų pranešimus / İmonių etika verslo praktikoje. Versta iš vok.k. / red. T. Bausch, A. Kleinfeld, H. Steinmann. Apžvalginis straipsnis N. Vasiljevienè. - Vilnius; VU KHF, Verslo etikos centras.

29. Tosi, H. L., Rizzo, J. R., Carroll, S. J. (1994). Managing organizational behavior. 3rd ed. - Cambrige, Massachusetts, Blackwell Publishers.

30. Upchurh, R., Lashley, C. (2006). Time Resort Operations. Oxford: Elsevier Butterworth Heinemann.

31. Velasquez, M. G. (1992). Business ethics: components and cases. $3^{\text {rd }}$ ed. - New Jersey: Prentice-Hall, Inc.

32. Vitkiené, E. (2009). Business enterprises strategic management in the context of economic crisis // BRIDGES: Supplemenatry issue: Scientific Volume / Social Sciences in Global World: Possibilities, Challenges and PErspectives. Vol. 28, No. 39.

33. Vitkienè, E. (2011). Relationships between sustainable development of the future corporate ethos and external entities in a globalized economy // Managenemt Theory and Studies for Rural Business and Infrastructure Development / Research Papers, 2 (26).

34. Wonnacott, P., Wonnacott, R. (1993). Mikroekonomika. - Kaunas: Littera Universitati Vytauti Magni.

35. Wonnacott, P., Wonnacott, R. (1994). Makroekonomika. - Kaunas: Litterate Universitatis.

The paper submitted: Nowember 25, 2012

Prepared for publication: October 28, 2013

\section{Elena VITKIENĖ}

\section{RYŠYS TARP KORPORACIJOS ETOSO IR BESIMOKANČIOS BEI BESIPLĖTOJANČIOS ORGANIZACIJOS KINTANČIOJE EKONOMIKOS APLINKOJE}

\section{S a n t r a u k a}

Globalios rinkos ekonomikos sąlygomis korporacijos turi suvokti kintančios ekonomikos aplinkos iššūkius, suprasti visuomenèje vykstančius pokyčius, nuspèti vartotojų norus bei pateisinti jų lūkesčius. Mokslo ir technologijų pažangos eroje vartotojai tampa žinių visuomene. Žinių visuomenès vartotojai nori ir pageidauja prekių ar paslaugų kokybę ir naujas technologijas atitinkančiomis kainomis. Kintančiųjų didžiųjų makroekonomikos problemų - infliacijos ir nedarbo, augimo ir produktyvumo 
ittakoje kinta rinkos struktūra ir ekonominis efektyvumas. Krizès ir konfliktų skirtumai tarptautiniame versle pasireiškia iššūkiais, darančiais tiesioginę itaką korporacijų etosui. Rinkos iššūkiai, kintanti ekonomikos aplinka sudaro verslo įmonèms sąlygas naujoms galimybėms pasipelnyti, daryti etiškus ir neetiškus, legalius ir nelegalius susitarimus.

Imonès, kintančiomis rinkos ekonomikos sąlygomis, norèdamos būti konkurencingomis ir išlikti verslo pasaulyje, privalo savo organizacinę elgseną orientuoti ì besimokančios organizacijos modelį, grindžiamą siektinų vertybių, organizacine kultūra ir verslo etika, socialinio marketingo koncepcija, paslaugų marketingo filosofija, visuomenès ir vartotojų požiūriu, kurio pagrindu būtų išsaugotas ne tik ịmonès pelnas, bet ir vartotojų bei visuomenès gerovè.

Šiandien nepakanka îvardinti besimokančią organizaciją kaip besimokančių jos narių visumą, nes šiandiene problema yra ta, kad nuolat kintančioje rinkos ekonomikos aplinkoje, ištiktoje globalizacijos iššūkių, besimokanti organizacija nèra tik jos narių, kaip individų grupių link tobulejimo visuma. Tai nuolat besitobulinantis, operatyviai reaguojantis i išorès pokyčius socialinis, kultūrinis fenomenas glaudžioje sąveikoje su makrolygio (politiniais, ekonominiais, socialiniais, kultūriniais, technologiniais, aplinkosauginiais bei teisètvarkos) poveikio veiksniais, pastoviai atkreipiantis demesi i kintančius potencialios rinkos dalyvių reikalavimus. Nes egzistuoja ryšys ne tik tarp korporacijos etoso ir besimokančios, bet ir besiplètojančios organizacijos problemų, makrolygio veiksnių ittakoje su korporacijos etosu. Tokiu atveju egzistuoja ryšio supratimo trūkumas tarp korporacijos etoso ir ma- krolygio tyrimo metodologijos ir žiniu problema apie esamą situaciją kintančioje ekonomikos aplinkos visumoje. Todèl šios problemos nauju tyrimo objektu tapo ryšio tarp korporacijos etoso ir besimokančios organizacijos plètojimo kintančioje ekonomikos aplinkos įtakos veiksnių visuma bei tyrimo proceso modelis. Tikslas - apibrèžti ir pateikti korporacijos etosui, besimokančiai organizacijai išorès aplinkos poveikị / spaudimą žinių visuomenès, šios visuomenès vartotojų, kintančios ekonomikos aplinkos iššùkių kontekste. Tikslui pasiekti tiriamos problemos analizès pagrindu parengtas naujas konceptualus besimokančios bei besiplètojančios organizacijos kintančioje ekonomikos aplinkoje tyrimo proceso modelis.

Problemos tyrimo proceso modelis, iš tiesų, yra aktualus kiekvienai besiplètojančiai įmonei, norinčiai konkuruoti ir išlikti verslo pasaulyje, pabrèžiant šio tyrimo metodologijos naujumą, sisteminị požiūrị i šią visumą. Atlikus skirtingų mokslų (ekonomikos, socialinio marketingo, paslaugų marketingo, vadybos, organizacinès elgsenos, kultūros, verslo etikos) koncepcijų sisteminę analizę, pabrèžiama, kad šiandienine korporacijos organizacija nera tik jos narių, geranoriškai besimokančių individų visuma. Korporacijos etosui, jos sprendimams daro įtaką kintanti žinių visuomenè, šios visuomenès vartotojai, makroekonomikos (PESTEL, BPESTEL) problemos, kintančios ekonomikos aplinkos iššūkiai.

Remiantis skirtingų mokslų koncepcijomis, parengtas moksliniu pagrindu loginis naujas ryšio tarp ateities korporacijos etoso ir besimokančios bei besiplètojančios organizacijos kintančioje išorès aplinkoje atitikties tyrimo modelis, kuris turètų pasitarnauti šiandieninès problemos tyrimuose. 